Review

\title{
GDF15/GFRAL Pathway as a Metabolic Signature for Cachexia in Patients with Cancer
}

\author{
Darakhshan Sohail Ahmed ${ }^{1,2}$, Stéphane Isnard ${ }^{1,2,3}$, John Lin ${ }^{1,2}$, Bertrand Routy ${ }^{4,5}$, Jean-Pierre Routy ${ }^{1,2,6 \bowtie}$ \\ 1. Infectious Disease and Immunity in Global Health Program, Research Institute of McGill University Health Centre, Montreal, QC, Canada \\ 2. Division of Hematology and Chronic Viral Illness Service, McGill University Health Centre, Montreal, QC, Canada \\ 3. CIHR Canadian HIV Trials Network, Vancouver, BC \\ 4. Division of Hémato-oncologie, Centre hospitalier de l'Université de Montréal \\ 5. Centre de recherche du Centre hospitalier de l'Université de Montréal \\ 6. Division of Hematology, McGill University Health Centre, Montreal, QC, Canada \\ $\triangle$ Corresponding author: Dr. Jean-Pierre Routy. Email: jean-pierre.routy@mcgill.ca
}

(C) The author(s). This is an open access article distributed under the terms of the Creative Commons Attribution License (https://creativecommons.org/licenses/by/4.0/). See http://ivyspring.com/terms for full terms and conditions.

Received: 2020.07.06; Accepted: 2020.11.06; Published: 2021.01.01

\begin{abstract}
Cachexia is a metabolic mutiny that directly reduces life expectancy in chronic conditions such as cancer. The underlying mechanisms associated with cachexia involve inflammation, metabolism, and anorexia. Therefore, the need to identify cachexia biomarkers is warranted to better understand catabolism change and assess various therapeutic interventions. Among inflammatory proteins, growth differentiation factor-15 (GDF15), an atypical transforming growth factor-beta (TGF- $\beta$ ) superfamily member, emerges as a stress-related hormone. In inflammatory conditions, cardiovascular diseases, and cancer, GDF15 is a biomarker for disease outcome. GDF15 is also implicated in energy homeostasis, body weight regulation, and plays a distinct role in cachexia. The recent discovery of its receptor, glial cell line-derived neurotrophic factor (GDNF) family receptor a-like (GFRAL), sheds light on its metabolic function. Herein, we critically review the mechanisms involving GDF15 in cancer cachexia and discuss therapeutic interventions to improve outcomes in people living with cancer.
\end{abstract}

Key words: GDF15, GFRAL, Inflammation, cachexia, cancer

\section{Introduction}

Late stages of diseases such as chronic kidney disease, congestive heart failure, AIDS, and cancer are associated with a wasting syndrome called cachexia.[1-3] For patients with cancer, up to one-third of deaths are attributed to this syndrome. The term 'cachexia' comes from the Greek words "kakos" and "hexis," which means "bad condition". Cachexia is defined as a metabolic syndrome associated with extreme involuntary wasting of lean body mass (LBM) with or without loss of fat mass[4-9] The international consensus statement on the definition and classification of cancer cachexia in 2011[6] established criteria for diagnosing cachexia in patients living with cancer. According to the consensus, cancer cachexia is defined as a loss of edema-free body weight of more than five percent over six months or loss of body weight of more than two percent in patients with a BMI of less than 20 $\mathrm{kg} / \mathrm{m}^{2} \cdot[5,7,10]$
Weight loss and muscle strength are predictors of mortality in patients with AIDS and cancer.[5, 11-13] However, in contrast to malnutrition and starvation which are treated with refeeding, cachexia is not corrected by conventional nutritional support and it is associated with loss of appetite (anorexia).[5, 14, 15] It is estimated that systemic inflammation, anorexia, and changes in energy metabolism are the main factors in the development of cachexia. $[4,14,16]$ Inflammation leading to LBM wasting is induced by both tumor and host-derived factors.[7] However, the underlying pathophysiology of cachexia remains poorly understood.[8, 17] Moreover, cancer-related anorexia and weight loss remain often untreatable and are associated with treatment resistance.[16] Therefore, a thorough understanding of the underlying mechanism of weight loss and anorexia is crucial in identifying a metabolic marker that can serve as both a prognostic indicator and a potential 
therapeutic target in cachexia.[14, 16]

\section{Cachexia in Cancer: As a Late Stage Feature}

For cancer patients, cachexia represents a life-threatening condition. Almost eighty percent of advanced cancer patients are affected by involuntary wasting, which is inversely related to handgrip strength, high toxicities of anti-cancer drugs, quality of life, and survival.[7, 11, 14, 16] For many years scientists and physicians focused efforts on cancer itself, as cachexia was considered a direct consequence of tumor progression. However, cachexia emerges as a distinct condition driven by the combination of inflammation and anorexia creating an overzealous metabolic imbalance in the host.[7, 8, $14,18]$ The key mechanism underlying cachexia is the increased catabolism of muscle protein combined with dampened protein synthesis, leading to LBM loss.[18]

Since cachexia preferentially causes loss of LBM more than FM, there is a need for a biomarker for the early diagnosis of cachexia, especially the atrophy in skeletal muscle.[6, 14] Despite several well-designed interventional clinical trials, cachexia cannot be reversed by conventional nutritional support, appetite stimulant, and recombinant growth hormone.[19] Specifically, the loss of muscle mass is recognized as an independent predictor of mortality and a major contributor to functional impairment.

In recent years, several markers have been reported to be involved in skeletal muscle atrophy in cancer cachexia.[8] These noteworthy mediators include the members of the TGF $\beta$ family such as Activin (Act) A,[20, 21] growth differentiation factor-11 (GDF11),[22, 23] GDF15,[16, 24], and Myostatin (Mstn).[14, 25-27] In 2010, Zhou et al. demonstrated reversal of cancer cachexia by injecting anti-bodies against Act $\mathrm{A}$ and Mstn in mice model leading to prolong survival.[20] Recently, a unique role of the inflammatory growth factor GDF15 has been highlighted in many studies using animal and human models of cancer cachexia.[7, 8, 28] A study by Lerner et al., demonstrated that GDF15 inhibitors reversed the loss of LBM and FM in mice.[8] These animal studies showed the contribution of inflammatory mediators involved in cachexia.

\section{Cachexia: A Metabolic Mutiny against Host}

In 2005, Fouladiun et al. found that cancer-related weight loss was linked to changes in the diet and inflammatory cytokines.[5, 29] Later, several groups reported on the secretion of cachectic factors by the tumor stroma and adjacent immune cells, which were associated with loss of both LBM and FM. $[6,7,15]$ Lipid metabolism was also affected as increased lipolysis and reduced lipogenesis in the adipocytes were observed during cachexia.[30] Pro-inflammatory cytokines such as IL-1, IL-6, IL-8, $\mathrm{TNFa}$, and IFNY acted directly or indirectly on the appetite centers of the central nervous system causing anorexia.[8, 14, 16, 31, 32] Moreover, the use of anti-TNFa or anti-IL-6 monoclonal antibodies did not influence survival or weight loss.[8, 19, 33, 34]. This suggests the need for a better understanding of the pathogenesis of cachexia that can serve both as a prognostic indicator and as a therapeutic target for reversing weight loss.[14] In humans, however, several clinical trials are ongoing to modulate plasma cytokines to revert cancer cachexia using NGM120 agent and GDF15 with induction chemotherapy.[14, 33] (Table 1).

\section{Contribution of Gdf15 to Anorexia and Cachexia}

Almost two decades ago GDF15 was identified as a member of the TGF- $\beta$ superfamily.[7, 35-37] Although it has been given different names, including macrophage inhibitory cytokine 1 (MIC-1), NSAID activated gene 1 (NAG-1), placental bone morphogenetic protein (PLAB), placental transforming growth factor-beta (PTGFB), prostate derived factor (PDF), following Strelau et al.'s recommendation in 2000, the protein was coined growth differentiation factor 15 (GDF15).[35, 38, 39] Outside its role in the placenta, GDF15 is a stress-induced hormone that is released by many tissues including vascular smooth muscle, cardiac and endothelial cells, macrophages, and adipocytes in response to diverse pro-inflammatory conditions such as obesity, insulin resistance, heart failure, and cancer.[7, 40,41] In relatively healthy individuals, the levels of GDF15 rise with age, intense exercise, obesity, smoking, pregnancy, and use of metformin.[42-45] GDF15 is expressed in higher concentrations in the placenta and prostate and is released in homeostatic conditions in smaller amounts by other tissues such as the liver, colon, stomach, heart, lungs, bladder, and kidneys. Conversely, higher levels are released by tissue damage and stress creating a peripheral non-homeostatic regulation of neural circuitry.[7, 39, 41, 43, 46, 47] Plasma levels usually range from 100 to $1200 \mathrm{pg} / \mathrm{ml}$, and a biphasic pattern in serum GDF15 levels was observed with a peak around midnight. [43, 48, 49]

Several studies demonstrated the overexpression of GDF15 in many advanced cancers such as prostate, urothelial, breast, gastric, colorectal, and 
esophagus.[24, 28, 47, 50, 51] In advanced cancers, the circulating levels of GDF15 might surge up to 10,000$100,000 \mathrm{pg} / \mathrm{mL}$.[24, 48, 52] Furthermore, a negative association between the increased plasma levels of GDF15 and survival was found in many cancers.[28, 50, 51, 53-57] In 2007, Johnen et al. injected GDF15 subcutaneously into mice which caused a rapid decrease in food intake and hence, a decline in weight.[24, 28] Moreover, Macia et al. in 2012 further demonstrated that the overexpression of GDF15 in tumors led to the inhibition of food intake in an animal model which subsequently causes loss of both LBM and FM.[58] Circulating levels of GDF15 and subsequent weight loss were associated with the stage and extent of disease progression and with all-cause mortality.[58]

GDF15 may have a context-dependent role in cancers: an antitumorigenic role of GDF15 was observed in early cancer while an association of GDF15 with the induction of tumor growth was observed in advanced cancer depending on a tumor type and its micro-environment.[28, 35, 46, 47] Early in the disease, the overexpression of GDF15 in cancer cells is speculated to be involved in the induction of apoptosis, and hence, anti-tumorigenicity.[28] Studies demonstrated a chemoprotective role of GDF15 in colon cancer and colonic polyps in mice models.[59-61] Similarly, one study in 2002 showed the anti-angiogenic properties of GDF15 in-vivo and in-vitro studies which were responsible for its anti-tumorigenic effect.[62] Later it was found that elevated levels of GDF15 are implicated in the causation of both chronic inflammation and tumorigenicity.[28] Brown et al. demonstrated a strong association of elevated plasma GDF15 levels with metastasis in prostate cancer.[51] Another study performed on 41 patients with testicular carcinoma, revealed the association of elevated levels of GDF15 with endothelial damage.[63] Globally, GDF15 in cancer seems to plays an anti-tumorigenic response to limit tumor growth at the early stages of cancer development while in the later stages, tumors may use GDF15 to escape immune surveillance to expand.[46]

Table 1: Ongoing clinical trials in patients with cancer cachexia.

\begin{tabular}{|c|c|c|c|c|c|c|c|}
\hline Study & Study type & Study title & Phase & Intervention/treatment & Time frame & Participants & Location \\
\hline NCT04068896 & $\mathrm{RCT}$ & $\begin{array}{l}\text { A Phase } 1 \mathrm{a} / \mathrm{b} \text { dose escalation study followed } \\
\text { by expansion cohorts of NGM120, a GFRAL } \\
\text { antagonist monoclonal antibody } \\
\text { blocking GDF15 signaling, in subjects with } \\
\text { advanced solid tumors receiving combination } \\
\text { therapy }\end{array}$ & $\begin{array}{l}\text { Phase } 1 \mathrm{a} / \mathrm{b} \\
\text { dose-escalation } \\
\text { study }\end{array}$ & $\begin{array}{l}\text { NGM120 } \times 6 \text { doses of } \\
\text { Subcutaneous injection }\end{array}$ & 19 weeks & $\mathrm{n}=90$ & $\begin{array}{l}\text { United } \\
\text { States }\end{array}$ \\
\hline NCT02285530 & $\mathrm{RCT}$ & $\begin{array}{l}\text { GDF15 based TPF induction chemotherapy } \\
\text { for oral squamous cell carcinoma patients at } \\
\text { T3/T4cN0M0 stage }\end{array}$ & Phase 2 & $\begin{array}{l}\text { TPF induction } \\
\text { chemotherapy } \\
\text { docetaxel: } 75 \mathrm{mg} / \mathrm{m} 2 ; \\
\text { cisplatin: } 75 \mathrm{mg} / \mathrm{m} 2 ; \\
\text { 5-Fu: } 750 \mathrm{mg} / \mathrm{m} 2 / \text { day (2 } \\
\text { cycles) }\end{array}$ & 2 years & $\mathrm{n}=72$ & China \\
\hline NCT03743051 & $\begin{array}{l}\text { RCT, double-blind, } \\
\text { placebo-controlled }\end{array}$ & $\begin{array}{l}\text { Efficacy and safety of Anamorelin } \mathrm{HCl} \text { in } \\
\text { adult patients with advanced Non-Small Cell } \\
\text { Lung Cancer }\end{array}$ & Phase 3 & $\begin{array}{l}\text { Anamorelin Hydrochloride } \\
\text { 100mg oral tablets } \\
\text { Drug: Placebo Oral Tablet }\end{array}$ & $\begin{array}{l}9 \text { weeks } \\
\text { from } \\
\text { baseline }\end{array}$ & $\mathrm{n}=316$ & $\begin{array}{l}\text { United } \\
\text { States }\end{array}$ \\
\hline NCT03283488 & RCT, double-blind & Mirtazapine vs. Megestrol & Phase 3 & $\begin{array}{l}\text { Mirtazapine } 15 \mathrm{mg} \text { oral } \\
\text { tablet vs. Megestrol } 160 \mathrm{mg} \\
\text { oral tablet }\end{array}$ & 8 weeks & $\mathrm{n}=40$ & Brazil \\
\hline NCT01614990 & RCT Pilot study & A pilot clinical trial of Macimorelin & Phase 2 & $\begin{array}{l}\text { Macimorelin }(1 \mathrm{mg} / \mathrm{kg}) \\
\text { daily }\end{array}$ & 7 days & $\mathrm{n}=8$ & $\begin{array}{l}\text { United } \\
\text { States }\end{array}$ \\
\hline NCT03207724 & $\begin{array}{l}\text { Interventional Clinical } \\
\text { Trial } \\
\text { Single Group } \\
\text { Assignment }\end{array}$ & $\begin{array}{l}\text { A Phase I study of Onivyde and 5-FU in } \\
\text { combination with Xilonix for advanced } \\
\text { pancreatic cancer }\end{array}$ & Phase 1 & $\begin{array}{l}\text { Xilonix plus Onivyde and } \\
\text { 5FU (IV) }\end{array}$ & $\begin{array}{l}28 \text { days, } 6 \\
\text { months, } 12 \\
\text { months } \\
\text { from } \\
\text { baseline }\end{array}$ & $\mathrm{n}=16$ & $\begin{array}{l}\text { United } \\
\text { States }\end{array}$ \\
\hline NCT03263520 & $\mathrm{RCT}$ & $\begin{array}{l}\text { Nandrolone on the treatment of malnutrition } \\
\text { induced by cancer }\end{array}$ & Phase 1 & $\begin{array}{l}\text { Nandrolone Decanoate } 25 \text { or } \\
50 \mathrm{mg}(\mathrm{M}), 25 \mathrm{mg}(\mathrm{F}) \mathrm{IM} \text { and } \\
\text { Dexamethasone } 4 \mathrm{mg} \text { for } \\
\text { M\&F }\end{array}$ & 30 days & $\mathrm{n}=60$ & Brazil \\
\hline NCT03254173 & RCT & Mirtazapine for treatment of cancer patients & $\begin{array}{l}\text { Phase } 2 \\
\text { Phase } 3\end{array}$ & $\begin{array}{l}\text { Mirtazapine } 30 \mathrm{mg} \text { oral } \\
\text { tablets } \\
\text { Placebo oral tablets }\end{array}$ & 8 weeks & $\mathrm{n}=120$ & Egypt \\
\hline NCT02359123 & $\begin{array}{l}\text { Interventional Clinical } \\
\text { Trial- Pilot Study }\end{array}$ & $\begin{array}{l}\text { Cannabidiol capsules as a treatment to } \\
\text { improve cancer-related cachexia and anorexia } \\
\text { syndrome in advanced cancer patients }\end{array}$ & Phase 1 & $\begin{array}{l}\text { Cannabis extract in an oil } \\
\text { formulation capsules } 5 \mathrm{mg}\end{array}$ & 3 months & $\mathrm{n}=24$ & Israel \\
\hline
\end{tabular}



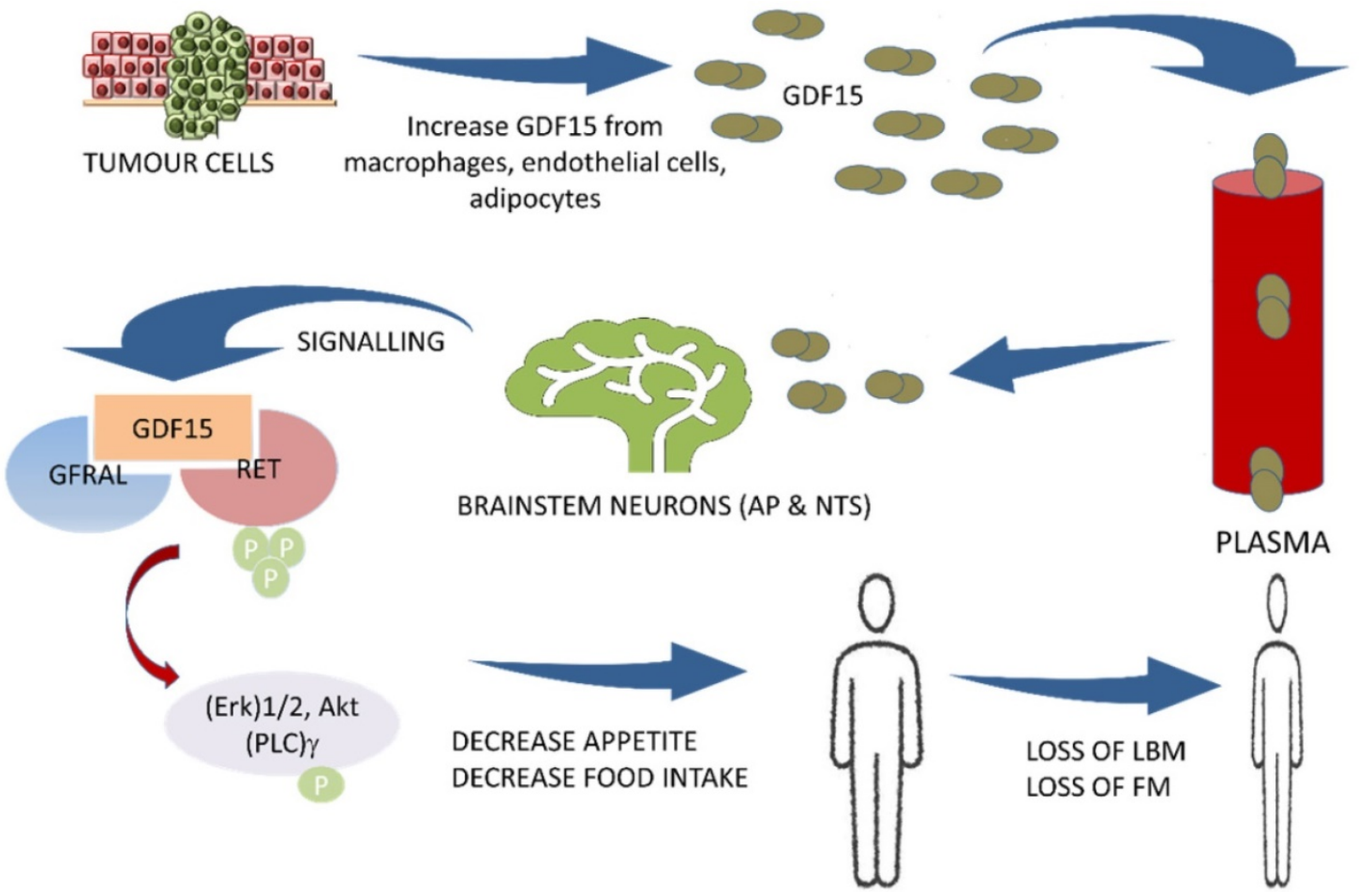

Figure 1: The central pathway of cancer cachexia involving GDF15 and GFRAL with RET proto-oncogene as a coreceptor. AP: area postrema; NTS: nucleus of solitary tract; GDF15: growth differentiation factor15; GFRAL: GDNF family receptor alpha-like; RET: rearranged during transfection proto-oncogene, a co-receptor to GFRAL; Erk: extracellular-signal-regulated kinase; Akt: Ak strain transforming; (PLC) $\gamma$ : phospholipase C-gamma; LBM: Lean body mass; FM: fat mass

In one animal study, GDF15 was identified as the only biomarker for the loss of skeletal muscle and weight in cancer.[16] Both GDF15 and to a lesser extent IL-8 were inversely linked to survival.[16, 64] Interestingly, weight loss was reversed by the administration of monoclonal antibodies against GDF15 and restored skeletal muscle and FM in several cachectic animal models.[8, 15, 16, 28, 46] Additionally, antibody-treated mice exhibited increased food intake, better locomotor function, energy expenditure, and resulted in de novo synthesis of muscle and adipose tissue.[8] A combination of tivozanib, an oral VEGF receptor tyrosine kinase inhibitor, and a GDF15 inhibitor further resulted in increased survival owing to the reversal of weight loss as compared to the control.[8] Such study findings indicate that GDF15 is much more than a biomarker of anorexia as it induces a distinctive "metabolic signature" characterized by enhanced lipid oxidation and muscle atrophy, leading to cachexia.[65]

\section{Gdf15 and the Identification of its Neuroreceptor Gfral}

In 2017, the GDF15 receptor was identified as the glial cell-derived neurotrophic factor (GDNF) family receptor alpha-like (GFRAL) expressed in the brainstem. $[3,40,66,67]$ The GDF15/GFRAL pathway has emerged as a key regulator of energy balance and anorexia. By binding to its neuroreceptor GFRAL,
GDF15 induces a dramatic reduction in appetite, LBM, and FM.[16] Furthermore, it was found that recombinant GDF15 suppresses food intake, regulates energy expenditure, and enhances weight loss through interactions with its unique brainstem-restricted neurotropic receptor, GFRAL.[7, 36, 40, 41, 44, 48] GDF15 acts specifically on the appetite center in the hypothalamus and brainstem mainly the area postrema (AP) and nucleus of the solitary tract (NTS) and controls the appetite centrally.[3, 18, 40, 68] The complex of GDF15 and GFRAL with its co-receptor the proto-oncogene RET (rearranged during transfection) causes activation with subsequent phosphorylation of intracellular signaling molecules, (Erk)1/2: extracellular signal-regulated kinase, Akt: Ak strain tranforming, and (PLC) $\gamma$ : phospholipase C-gamma.[18, 40] (Figure 1) It is well established that GDF15 regulates food intake, energy expenditure, and body weight in response to metabolic and toxin-induced stresses in cancer. Furthermore, the mechanism regulating the GDF15 metabolic effect has recently been identified. In 2015, Tsai et al. showed an absence of a postprandial increase in GDF15 serum levels in healthy participants suggesting that it is unlikely that this hormone acts as a 'satiety factor'.[47] O'Rahilly et al., in 2017 showed that GDF15 serum levels induced a minimal change in response to caloric surpluses or deficits in both mice and humans, differentiating its 
action from intestinally derived satiety hormones and leptin. Furthermore, the same group showed that GDF15 expression was regulated by the tissue stress response in mice, and its administration triggered conditioned taste aversion suggesting that GDF15 induces an aversive response to nutritional stress.[69] In addition, Patel et al. in 2019, also demonstrated that GDF15 administration triggered conditioned taste aversion via GFRAL, while Borner et al. showed that GDF15 Induces anorexia through nausea and emesis in the mouse model. Globally, these findings indicate that GDF15 does not act as an 'anti-hunger' hormone or has any 'satiety effect' but induces an aversive response to nutritional stress. [44, 70] GDF-15 and GFRAL signaling pathways are thus suggested to be an important potential therapeutic target for both cancer cachexia and obesity.[7, 16, 42, 46, 54, 71] Thus, both GDF15 and GFRAL signaling through the tyrosine kinase receptor RET[18, 46] are under investigation in several clinical trials.[43, 46] (Table 1)

\section{Gdf15 Induces Anorexia, Lipid Oxidation, and Muscle Atrophy via Neuroendocrine Axis}

It was established in the 1980s that the $\beta$ adrenergic stimulation causes increase lipolysis and inhibit the activity of the lipoprotein lipase resulting in increased plasma triglycerides.[72] In 2019, Luan et al. identified novel characteristics of GDF15 in disease tolerance in the context of infection. This group showed in a mouse model that GDF15 is induced in inflammatory diseases through the central induction of metabolic adaptation and contribute to a protective effect in organ damage. This inflammation-induced tolerance effect is achieved by metabolic reprogramming and the production of triglycerides via hepatic sympathetic outflow, hence preventing cardiac damage after an LPS endotoxemic challenge.[73] Such protective activity on tissue after the infection is achieved by central activation via the GFRAL receptor and production of norepinephrine with subsequent stimulation of the liver to produce and release triglycerides.[47, 73, 74] These findings are supported by previous reports on the cardioprotective role of GDF15 in the context of inflammation and infection.[75, 76] However, the relevance of the GDF15 adrenergic pathway contribution in cancer cachexia, which is also characterized by increased lipolysis, was not determined.[30, 73]

In August 2020, Suriben et al. were the first to link the GDF15/GRFAL sympathetic pathway with the hepatic lipid oxidation in a cancer cachexia mouse model.[65] The injection of a monoclonal antibody antagonist that targets GFRAL and inhibit Ret proto-oncogene (RET) signaling complex in brainstem neurons (area postrema: AP; and nucleus of solitary tract: NTS) reversed excessive lipid oxidation in tumor-bearing mice and prevents cancer cachexia.[65] Furthermore, to unveil the mechanism of action of GDF15, the same group showed that activation of the GFRAL-RET pathway induces the expression of genes involved in lipid metabolism in adipose tissues. They also showed that chemical peripheral sympathectomy and the loss of adipose triglyceride lipase protect mice from GDF15-induced weight loss in the context of cancer.[65] This ground-breaking observation demonstrated the role of the peripheral sympathetic axis by which GDF15 elicits a lipolytic response in adipose tissue independently of anorexia, contributing to the reduction in both, adipose and muscle mass in tumor-bearing mice.

\section{Challenges of Blocking Gdf15/Gfral Pathway: Consideration for Cachexia and Cancer Progression}

Despite the breakthrough in inhibiting the GDF15/GFRAL pathway for the treatment of cachexia in the mouse model, several issues concerning interplay between host and tumor must be addressed for cachectic cancer patients.[65]

\section{Effect on cachexia}

For most patients with metastatic cancers, the cause of death is due to cachexia more than the direct effect of tumor bulk and organ failure. Based on the absence of any therapy for improving cachexia and on similar mechanistic evidence in the animal model and human, clinical trials testing anti-GDF15/GFRAL treatments appear promising, specifically in patients with elevated circulating GDF15 levels.[65] Considering the limited clinical consequence of GDF15 knock-out mice, acceptable tolerability can be expected. Still, due to the limited sequence homology between mice and human GDF15, studies in humans may not fully replicate those from mouse models.

\section{Effect on cancer progression}

Beyond its cachectic effect, GDF15 has been also implicated in tumor cell apoptosis and the development of metastasis. In addition, GDF15 can also modulate the tumor microenvironment, innate immune surveillance, and response to immunetherapy.[77] As the tissue distribution of GFRAL is limited to the hindbrain, direct effects of GDF15 on cancer or microenvironment immune cells may be mediated by yet unidentified GFRAL-independent signaling pathways.[47] As such, consequences of direct inhibition of GDF15 on the tumor itself may be more difficult to predict. Encouragingly, recent study findings suggest that blockade of GDF15 has the 
potential to reverse anorexia while improving response immunotherapies.[47]

Globally, considering both host and cancer factors, only the completion of clinical trials using an inhibitor of the GDF15/GFRAL pathway will provide clinical evidence on the merit of reversing this "metabolic signature" to improve the lives of those living with advanced cancer.[78-81]

\section{Conclusion}

GDF15 plasma level correlates with tumor progression and has been considered as a tumor biomarker.[47, 55, 82-86] Functionally, GDF15 is now considered as the main actor of cachexia in cancer signaling through its neuroreceptor GFRAL. However, via an adrenergic pathway GDF15 can stimulate hepatic triglyceride release to protect tissues from inflammatory stress. Overall, reports of GDF15-dependent effects in cancer are context-dependent and mainly studied in animal models. Therefore, results from ongoing clinical trials in human models inhibiting the GDF15/GFRAL pathway will shed light on patients with cancer cachexia. Due to the complex contribution of cancer and host factors, combination therapy including GDF15 blockade along with chemotherapy/ immunotherapy will likely be needed to reverse cachexia metabolic signature, which in turn will improve the lives of persons living with cancer.

\section{Abbreviations}

GDF15: growth differentiation factor 15; GFRAL: glial cell line-derived neurotrophic factor (GDNF) family receptor a-like; HIV: human immunodeficiency virus; AIDS: acquired immune deficiency syndrome; LBM: lean body mass; FM: fat mass; TGF 3 : transforming growth factor-beta; Act A: activin A; GDF11: growth differentiation factor 11; Mstn: myostatin; IL: interleukin; TNFa: tumor necrosis factor-alpha; IFN $\gamma$ : interferon-gamma; BMI: basal mass index; MIC-1: macrophage inhibitory cytokine 1; NAG-1: NSAID activated gene 1; PLAB: placental bone morphogenetic protein; PTGFB: placental transforming growth factor-beta; PDF: prostate derived factor; VEGF: vascular endothelial growth factor; AP: area postrema; NTS: nucleus of solitary nucleus; RET: rearranged during transfection; LPS: lipopolysaccharide; Erk: extracellular signal-regulated kinase; Akt: Ak strain transforming; (PLC) $\gamma$ : phospholipase C-gamma.

\section{Acknowledgements}

Our research is funded by the Fonds de la Recherche Québec-Santé (FRQ-S): Réseau SIDA/ Maladies infectieuses and Thérapie cellulaire; the
Canadian Institutes of Health Research (CIHR; grants MOP 103230 and PTJ 166049); the Vaccines \& Immunotherapies Core of the CIHR Canadian HIV Trials Network (CTN; CTN PT038); CIHR- funded Canadian HIV Cure Enterprise (CanCURE) Team Grant HB2-164064.

SI is supported by research fellowships from Fonds de la Recherche Quebec-Science (FRQ-S) and the Canadian Institutes of Health Research (CIHR) HIV trial network (CTN). BR is a Junior I Physician-Scientist supported by FRQ-S and J-PR holds a Louis Lowenstein Chair in Hematology and Oncology, from McGill University.

\section{Author Contributions}

DSA contributed to the planning of the manuscript, performed the literature review, and wrote the first and final draft of the manuscript. SI, JL, and BR participated in the planning of the manuscript, reviewed the first draft, and approved the final draft of the manuscript. JPR conceived and designed the manuscript, contributed to the literature review, reviewed the manuscript drafts, and approved the final version. SI, JL, BR, and DSA provided critical revision of the manuscript. All authors approved it for publication.

\section{Competing Interests}

The authors have declared that no competing interest exists.

\section{References}

1. Unsicker K, Spittau B, Krieglstein K. The multiple facets of the TGF- $\beta$ family cytokine growth/differentiation factor-15/macrophage inhibitory cytokine-1. Cytokine \& growth factor reviews. 2013;24(4):373-84.

2. Secemsky EA, Scherzer R, Nitta E, Wu AH, Lange DC, Deeks SG, et al. Novel biomarkers of cardiac stress, cardiovascular dysfunction, and outcomes in HIV-infected individuals. JACC: Heart Failure. 2015;3(8):591-9.

3. Mullican SE, Lin-Schmidt X, Chin C-N, Chavez JA, Furman JL, Armstrong AA, et al. GFRAL is the receptor for GDF15 and the ligand promotes weight loss in mice and nonhuman primates. Nature medicine. 2017;23(10):1150.

4. Vanhoutte G, van de Wiel M, Wouters K, Sels M, Bartolomeeussen L, De Keersmaecker S, et al. Cachexia in cancer: what is in the definition? BMJ open gastroenterology. 2016;3(1):e000097.

5. Evans WJ, Morley JE, Argilés J, Bales C, Baracos V, Guttridge D, et al. Cachexia: A new definition. Clinical Nutrition. 2008;27(6):793-9.

6. Fearon K, Strasser F, Anker SD, Bosaeus I, Bruera E, Fainsinger RL, et al. Definition and classification of cancer cachexia: an international consensus. The lancet oncology. 2011;12(5):489-95.

7. Tsai V, Lin S, Brown D, Salis A, Breit S. Anorexia-cachexia and obesity treatment may be two sides of the same coin: role of the TGF-b superfamily cytokine MIC-1/GDF15. International journal of obesity. 2016;40(2):193-7.

8. Lerner L, Tao J, Liu Q, Nicoletti R, Feng B, Krieger B, et al. MAP3K11/GDF15 axis is a critical driver of cancer cachexia. Journal of cachexia, sarcopenia and muscle. 2016;7(4):467-82

9. Kralisch S, Hoffmann A, Estrada-Kunz J, Stumvoll M, Fasshauer M, Tönjes A, et al. Increased Growth Differentiation Factor 15 in Patients with Hypoleptinemia-Associated Lipodystrophy. International Journal of Molecular Sciences. 2020;21(19):7214.

10. Kimura M, Naito T, Kenmotsu H, Taira T, Wakuda K, Oyakawa T, et al. Prognostic impact of cancer cachexia in patients with advanced non-small cell lung cancer. Supportive Care in Cancer. 2015;23(6):1699-708.

11. Vigano A, Donaldson N, Higginson IJ, Bruera E, Mahmud S, Suarez-Almazor M. Quality of life and survival prediction in terminal cancer patients: a multicenter study. Cancer. 2004;101(5):1090-8.

12. Tang AM, Forrester J, Spiegelman D, Knox TA, Tchetgen E, Gorbach SL. Weight loss and survival in HIV-positive patients in the era of highly active 
antiretroviral therapy. Journal of acquired immune deficiency syndromes (1999). 2002;31(2):230-6.

13. Wheeler DA, Gibert CL, Launer CA, Muurahainen N, Elion RA, Abrams DI, et al. Weight loss as a predictor of survival and disease progression in HIV infection. Terry Beirn Community Programs for Clinical Research on AIDS. Journal of acquired immune deficiency syndromes and human retrovirology: official publication of the International Retrovirology Association. 1998;18(1):80-5.

14. Loumaye A, Thissen J-P. Biomarkers of cancer cachexia. Clinical biochemistry. 2017;50(18):1281-8.

15. Tsai VW, Husaini Y, Manandhar R, Lee- $\mathrm{Ng} \mathrm{KM}$, Zhang HP, Harriott K, et al. Anorexia/cachexia of chronic diseases: a role for the TGF- $\beta$ family cytokine MIC-1/GDF15. Journal of cachexia, sarcopenia and muscle. 2012;3(4):239-43.

16. Lerner L, Hayes TG, Tao N, Krieger B, Feng B, Wu Z, et al. Plasma growth differentiation factor 15 is associated with weight loss and mortality in cancer patients. Journal of cachexia, sarcopenia and muscle. 2015;6(4):317-24.

17. Kotler D. Challenges to diagnosis of HIV-associated wasting. JAIDS Journal of Acquired Immune Deficiency Syndromes. 2004;37:S280-S3.

18. Breit SN, Tsai VW-W, Brown DA. Targeting obesity and cachexia: identification of the GFRAL receptor-MIC-1/GDF15 pathway. Trends in Molecular Medicine. 2017;23(12):1065-7.

19. Fearon $K$, Arends J, Baracos V. Understanding the mechanisms and treatment options in cancer cachexia. Nature reviews Clinical oncology. 2013;10(2):90.

20. Zhou X, Wang JL, Lu J, Song Y, Kwak KS, Jiao Q, et al. Reversal of cancer cachexia and muscle wasting by ActRIIB antagonism leads to prolonged survival. Cell. 2010;142(4):531-43.

21. Chen JL, Walton KL, Qian H, Colgan TD, Hagg A, Watt MJ, et al. Differential effects of IL6 and activin A in the development of cancer-associated cachexia. Cancer research. 2016;76(18):5372-82.

22. McPherron AC, Huynh TV, Lee S-J. Redundancy of myostatin and growth/differentiation factor 11 function. BMC developmental biology. 2009;9(1):24

23. Hammers DW, Merscham-Banda M, Hsiao JY, Engst S, Hartman JJ, Sweeney HL. Supraphysiological levels of GDF 11 induce striated muscle atrophy. EMBO molecular medicine. 2017;9(4):531-44.

24. Johnen H, Lin S, Kuffner T, Brown DA, Tsai VW-W, Bauskin AR, et al. Tumor-induced anorexia and weight loss are mediated by the TGF- $\beta$ superfamily cytokine MIC-1. Nature medicine. 2007;13(11):1333-40.

25. Ebner N, Steinbeck L, Doehner W, Anker SD, von Haehling S. Highlights from the 7th Cachexia Conference: muscle wasting pathophysiological detection and novel treatment strategies. Springer; 2014

26. McPherron AC, Lawler AM, Lee SJ. Regulation of skeletal muscle mass in mice by a new TGF-beta superfamily member. Nature. 1997;387(6628):83-90.

27. Trendelenburg AU, Meyer A, Rohner D, Boyle J, Hatakeyama S, Glass DJ. Myostatin reduces Akt/TORC1/p70S6K signaling, inhibiting myoblast differentiation and myotube size. American Journal of Physiology-Cell Physiology. 2009;296(6):C1258-C70

28. Breit SN, Johnen H, Cook AD, Tsai VW, Mohammad MG, Kuffner T, et al. The TGF- $\beta$ superfamily cytokine, MIC-1/GDF15: a pleotrophic cytokine with roles in inflammation, cancer and metabolism. Growth factors. 2011;29(5):187-95

29. Fouladiun M, Körner U, Bosaeus I, Daneryd P, Hyltander A, Lundholm KG. Body composition and time course changes in regional distribution of fat and lean tissue in unselected cancer patients on palliative care-correlations with food intake, metabolism, exercise capacity, and hormones. Cancer: Interdisciplinary International Journal of the American Cancer Society. 2005;103(10):2189-98

30. Daas SI, Rizeq BR, Nasrallah GK. Adipose tissue dysfunction in cancer cachexia. Journal of cellular physiology. 2019;234(1):13-22

31. Fearon KC, Glass DJ, Guttridge DC. Cancer cachexia: mediators, signaling, and metabolic pathways. Cell metabolism. 2012;16(2):153-66.

32. Onesti JK, Guttridge DC. Inflammation based regulation of cancer cachexia. BioMed research international. 2014;2014.

33. Grim-Stieger M, Keilani M, Mader R, Marosi C, Schmidinger M, Zielinski C, et al. Serum levels of tumour necrosis factor- $\alpha$ and interleukin- 6 and their correlation with body mass index, weight loss, appetite and survival ratepreliminary data of Viennese outpatients with metastatic cancer during palliative chemotherapy. European journal of cancer care. 2008;17(5):454-62.

34. Suh S-Y, Choi YS, Yeom CH, Kwak SM, Yoon HM, Kim DG, et al. Interleukin-6 but not tumour necrosis factor-alpha predicts survival in patients with advanced cancer. Supportive Care in Cancer. 2013;21(11):3071-7.

35. Coll AP, Chen M, Taskar P, Rimmington D, Patel S, Tadross JA, et al. GDF15 mediates the effects of metformin on body weight and energy balance. Nature. 2020;578(7795):444-8.

36. Day EA, Ford RJ, Smith BK, Mohammadi-Shemirani P, Morrow MR, Gutgesell RM, et al. Metformin-induced increases in GDF15 are important for suppressing appetite and promoting weight loss. Nature Metabolism. 2019;1(12):1202-8.

37. Chang JY, Hong HJ, Kang SG, Kim JT, Zhang BY, Shong M. The Role of Growth Differentiation Factor 15 in Energy Metabolism. Diabetes \& Metabolism Journal. 2020;44(3):363-71.

38. Strelau J, Böttner M, Lingor P, Suter-Crazzolara C, Galter D, Jaszai J, et al. GDF-15/MIC-1 a novel member of the TGF- $\beta$ superfamily. Advances in Research on Neurodegeneration: Springer; 2000. p. 273-6.

39. Emmerson PJ, Duffin KL, Chintharlapalli S, Wu X. GDF15 and growth control. Frontiers in physiology. 2018;9:1712
40. Hsu J-Y, Crawley S, Chen M, Ayupova DA, Lindhout DA, Higbee J, et al. Non-homeostatic body weight regulation through a brainstem-restricted receptor for GDF15. Nature. 2017;550(7675):255-9.

41. Adela R, Banerjee SK. GDF-15 as a target and biomarker for diabetes and cardiovascular diseases: a translational prospective. Journal of diabetes research. 2015;2015.

42. Routy J-P, Isnard S, Mehraj V, Ostrowski M, Chomont N, Ancuta P, et al. Effect of metformin on the size of the HIV reservoir in non-diabetic ART-treated individuals: single-arm non-randomised Lilac pilot study protocol. BMJ open. 2019;9(4):e028444

43. Mullican SE, Rangwala SM. Uniting GDF15 and GFRAL: Therapeutic Opportunities in Obesity and Beyond. Trends in Endocrinology \& Metabolism. 2018;29(8):560-70.

44. Patel S, Alvarez-Guaita A, Melvin A, Rimmington D, Dattilo A, Miedzybrodzka EL, et al. GDF15 provides an endocrine signal of nutritional stress in mice and humans. Cell metabolism. 2019;29(3):707-18. e8.

45. Isnard S, Lin J, Fombuena B, Ouyang J, Varin TV, Richard C, et al. Repurposing Metformin in Nondiabetic People With HIV: Influence on Weight and Gut Microbiota. Open forum infectious diseases; 2020: Oxford University Press US.

46. Tsai VW, Husaini Y, Sainsbury A, Brown DA, Breit SN. The MIC-1/GDF15-GFRAL pathway in energy homeostasis: implications for obesity, cachexia, and other associated diseases. Cell metabolism. 2018;28(3):353-68.

47. Wischhusen J, Melero I, Fridman WH. Growth/Differentiation Factor-15 (GDF-15): From Biomarker to Novel Targetable Immune Checkpoint. Frontiers in Immunology. 2020;11.

48. Tsai VW-W, Macia L, Feinle-Bisset C, Manandhar R, Astrup A, Raben A, et al. Serum levels of human MIC-1/GDF15 vary in a diurnal pattern, do not display a profile suggestive of a satiety factor and are related to BMI. PloS one. 2015;10(7):e0133362.

49. KS YHXFL. Wang Y Bao Y Zhang J Gu Y Zhou P Lu J Jia W Xu A. Circadian rhythm of circulating fibroblast growth factor 21 is related to diurnal changes in fatty acids in humans. Clinical Chemistry. 2011;57:691-700.

50. Ishige $T$, Nishimura $M$, Satoh $M$, Fujimoto $M$, Fukuyo $M$, Semba $T$, et al. Combined secretomics and transcriptomics revealed cancer-derived GDF15 is involved in diffuse-type gastric cancer progression and fibroblast activation. Scientific reports. 2016;6(1):1-11.

51. Brown DA, Lindmark F, Stattin P, Bälter K, Adami H-O, Zheng SL, et al. Macrophage inhibitory cytokine 1: a new prognostic marker in prostate cancer. Clinical cancer research. 2009;15(21):6658-64.

52. Bauskin AR, Brown DA, Kuffner T, Johnen H, Luo XW, Hunter M, et al. Role of macrophage inhibitory cytokine- 1 in tumorigenesis and diagnosis of cancer. Cancer research. 2006;66(10):4983-6.

53. Korbecki J, Gutowska I, Kojder I, Jeżewski D, Goschorska M, Łukomska A, et al. New extracellular factors in glioblastoma multiforme development: Neurotensin, growth differentiation factor-15, sphingosine-1-phosphate and cytomegalovirus infection. Oncotarget. 2018:9(6):7219.

54. Lee ES, Kim SH, Kim HJ, Kim KH, Lee BS, Ku BJ. Growth differentiation factor 15 predicts chronic liver disease severity. Gut and liver. 2017;11(2):276.

55. Traeger L, Ellermann I, Wiethoff H, Ihbe J, Gallitz I, Eveslage M, et al. Serum Hepcidin and GDF-15 levels as prognostic markers in urothelial carcinoma of the upper urinary tract and renal cell carcinoma. BMC cancer. 2019;19(1):1-10.

56. Urakawa N, Utsunomiya S, Nishio M, Shigeoka M, Takase N, Arai N, et al. GDF15 derived from both tumor-associated macrophages and esophageal squamous cell carcinomas contributes to tumor progression via Akt and Erk pathways. Laboratory investigation. 2015;95(5):491-503.

57. Si Y, Liu X, Cheng M, Wang M, Gong Q, Yang Y, et al. Growth differentiation factor 15 is induced by hepatitis $C$ virus infection and regulates hepatocellular carcinoma-related genes. PloS one. 2011;6(5)

58. Macia L, Tsai VW-W, Nguyen AD, Johnen H, Kuffner T, Shi Y-C, et al. Macrophage inhibitory cytokine 1 (MIC-1/GDF15) decreases food intake, body weight and improves glucose tolerance in mice on normal \& obesogenic diets. PloS one. 2012;7(4)

59. Zimmers TA, Gutierrez JC, Koniaris LG. Loss of GDF-15 abolishes Sulindac chemoprevention in the Apc Min/+ mouse model of intestinal cancer. Journal of cancer research and clinical oncology. 2010;136(4):571-6.

60. Baek SJ, Okazaki R, Lee S-H, Martinez J, Kim J-S, Yamaguchi K, et al. Nonsteroidal anti-inflammatory drug-activated gene-1 over expression in transgenic mice suppresses intestinal neoplasia. Gastroenterology. 2006;131(5):1553-60.

61. Kim J-S, Baek SJ, Sali T, Eling TE. The conventional nonsteroidal anti-inflammatory drug sulindac sulfide arrests ovarian cancer cell growth via the expression of NAG-1/MIC-1/GDF-15. Molecular cancer therapeutics. 2005;4(3):487-93.

62. Albertoni M, Shaw PH, Nozaki M, Godard S, Tenan M, Hamou M-F, et al. Anoxia induces macrophage inhibitory cytokine-1 (MIC-1) in glioblastoma cells independently of p53 and HIF-1. Oncogene. 2002;21(27):4212-9.

63. Altena R, Fehrmann RS, Boer H, de Vries EG, Meijer C, Gietema JA. Growth differentiation factor 15 (GDF-15) plasma levels increase during bleomycin-and cisplatin-based treatment of testicular cancer patients and relate to endothelial damage. PloS one. 2015;10(1):e0115372.

64. Gale CR, Martyn CN, Cooper C, Sayer AA. Grip strength, body composition, and mortality. International journal of epidemiology. 2007;36(1):228-35 
65. Suriben R, Chen M, Higbee J, Oeffinger J, Ventura R, Li B, et al. Antibody-mediated inhibition of GDF15-GFRAL activity reverses cancer cachexia in mice. Nature medicine. 2020;26(8):1264-70.

66. Emmerson PJ, Wang F, Du Y, Liu Q, Pickard RT, Gonciarz MD, et al. The metabolic effects of GDF15 are mediated by the orphan receptor GFRAL. Nature medicine. 2017;23(10):1215.

67. Yang L, Chang C-C, Sun Z, Madsen D, Zhu H, Padkjær SB, et al. GFRAL is the receptor for GDF15 and is required for the anti-obesity effects of the ligand. Nature medicine. 2017;23(10):1158.

68. Tsai VW-W, Manandhar R, Jørgensen SB, Lee-Ng KKM, Zhang HP, Marquis $\mathrm{CP}$, et al. The anorectic actions of the TGF $\beta$ cytokine MIC-1/GDF15 require an intact brainstem area postrema and nucleus of the solitary tract. PloS one. 2014;9(6).

69. O'Rahilly S. GDF15 - from biomarker to allostatic hormone. Cell metabolism. 2017;26(6):807-8

70. Borner T, Shaulson ED, Ghidewon MY, Barnett AB, Horn CC, Doyle RP, et al. GDF15 induces anorexia through nausea and emesis. Cell metabolism. 2020;31(2):351-62. e5.

71. Ouyang J, Isnard S, Lin J, Fombuena B, Peng X, Chen Y, et al. GDF-15 as a Weight Watcher for Diabetic and Non-diabetic People Treated with Metformin. Frontiers in Endocrinology. 2020;11:911.

72. Smith U. Adrenergic control of lipid metabolism. Acta Medica Scandinavica. 1983;213(S672):41-7.

73. Luan $\mathrm{HH}$, Wang A, Hilliard BK, Carvalho F, Rosen CE, Ahasic AM, et al. GDF15 Is an Inflammation-Induced Central Mediator of Tissue Tolerance. Cell. 2019;178(5):1231-44.e11.

74. McCarville JL, Ayres JS. Host-pathogen relationship advice: fat protects against a broken heart. Cell metabolism. 2019;30(3):409-11.

75. Abulizi P, Loganathan N, Zhao D, Mele T, Zhang Y, Zwiep T, et al. Growth differentiation factor-15 deficiency augments inflammatory response and exacerbates septic heart and renal injury induced by lipopolysaccharide. Scientific reports. 2017;7(1):1-10.

76. Kempf T, Eden M, Strelau J, Naguib M, Willenbockel C, Tongers Jr, et al. The transforming growth factor- $\beta$ superfamily member growth-differentiation factor-15 protects the heart from ischemia/reperfusion injury. Circulation research. 2006;98(3):351-60.

77. Vitale I, Manic G, Coussens LM, Kroemer G, Galluzzi L. Macrophages and metabolism in the tumor microenvironment. Cell metabolism. 2019;30(1):36-50.

78. Ratnam NM, Peterson JM, Talbert EE, Ladner KJ, Rajasekera PV, Schmidt CR, et al. NF-KB regulates GDF-15 to suppress macrophage surveillance during early tumor development. The Journal of clinical investigation. 2017;127(10):3796-809.

79. Roth P, Junker M, Tritschler I, Mittelbronn M, Dombrowski Y, Breit SN, et al. GDF-15 contributes to proliferation and immune escape of malignant gliomas. Clinical cancer research. 2010;16(15):3851-9.

80. Modi A, Dwivedi S, Roy D, Khokhar M, Purohit P, Vishnoi J, et al. Growth differentiation factor 15 and its role in carcinogenesis: an update. Growth factors. 2019;37(3-4):190-207.

81. Havel JJ, Chowell D, Chan TA. The evolving landscape of biomarkers for checkpoint inhibitor immunotherapy. Nature Reviews Cancer. 2019;19(3):133-50

82. Li C, Wang J, Kong J, Tang J, Wu Y, Xu E, et al. GDF15 promotes EMT and metastasis in colorectal cancer. Oncotarget. 2016;7(1):860.

83. Staff AC, Trovik J, Zahl EAG, Wik E, Wollert KC, Kempf T, et al. Elevated plasma growth differentiation factor-15 correlates with lymph node metastases and poor survival in endometrial cancer. Clinical cancer research. 2011;17(14):4825-33.

84. Brown DA, Lindmark F, Stattin P, Bälter K, Adami H-O, Zheng SL, et al Macrophage Inhibitory Cytokine 1: A New Prognostic Marker in Prostate Cancer. Clinical cancer research. 2009;15(21):6658.

85. Wang X, Li Y, Tian H, Qi J, Li M, Fu C, et al. Macrophage inhibitory cytokine 1 (MIC-1/GDF15) as a novel diagnostic serum biomarker in pancreatic ductal adenocarcinoma. BMC cancer. 2014;14(1):578.

86. Mehta RS, Song M, Bezawada N, Wu K, Garcia-Albeniz X, Morikawa T, et al. A prospective study of macrophage inhibitory cytokine-1 (MIC-1/GDF15) and risk of colorectal cancer. Journal of the National Cancer Institute. 2014;106(4):dju016. 